\section{Ethical political economy lessons from the Malay world through the Hikayat Abdullah 1849}

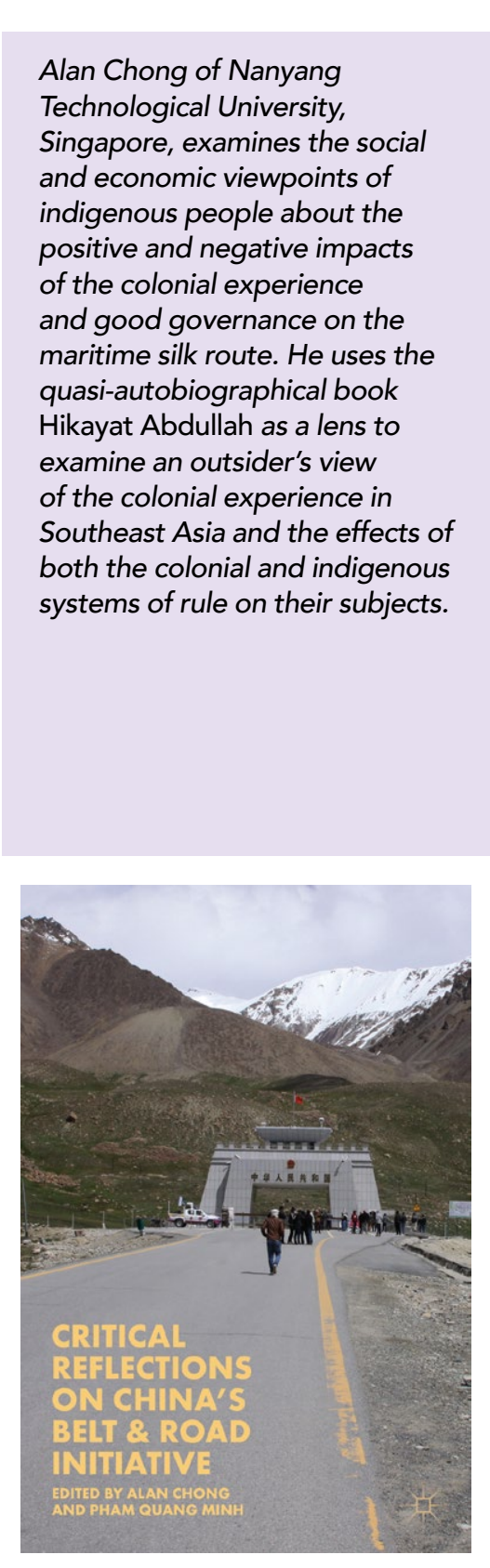

T Alan Chong of Nanyang Technological University,
Singapore examines the social d economic viewpoint of indigenous people about the positive and negative and good governance on the maritime silk route. Long before the European nations' colonial advances into Asia, globalisation had already occurred on the Silk Road. From as early as 200BCE, the land Silk Road joined China to Western Europe via the Indian sub-continent, Persia and modern-day Ukraine, while the maritime Silk Road hopped from port to port from China to present-day Vietnam, Philippines, Indonesia, Malaysia, Singapore, India, Sri Lanka, Persia, and the Arabian Gulf, and after a short land crossing, and finally Cadiz.

\section{THE SILK ROAD}

The Silk Road brought economic

but also spread ideas and beliefs, Hinduism, Buddhism, Christianity and Islam were all carried along with trade goods. Chong highlights a lesson from history given in 19th century Muslim trader Munshi Abdullah's autobiography Hikayat Abdullah, that what creates most benefit for the peoples of globalisation would be "impartial administration of law and order, beneficent autocracy, and the proper prioritisation between wealth and good manners." This is especially pertinent today as China President Xi Jinping pushes forward with the "new Slik Road" vision to invest Dr Alan Chong examines an outsider's view
the colonial experience in Southeast Asia. the Indian Ocean known as the "Belt and Road Initiative."

WHO WAS MUNSHI ABDULLAH? The Hikayat Abdullah, or the story of the teacher Abdullah, can be used progress from a Southeast Asian perspective. Munshi Abdullah was born into a family heavily involved in an incipient international economy, much like the middlle-class jet set professionals and global nomads of today, who live not within a nationalist paradigm, but on a global one that primarily seeks the creation of wealth.

His great-grandfather was an Arab religious teacher from Yemen, who ended up living in the ancient state of Kalinga in eastern India. Of his four sons, three went to live in Java, while his grandfather His father grew up there, used his family's trade connections to do business in the hinterland, and whose knowledge of Islam and the Koran led him to become a religious teacher and spread its beliefs. Because of his linguistic abilities, he managed to become a regional fixer, including for the Dutch, and conducted business in ports as far away as Java.

Thus Munshi Abdullah was equipped, like his father, with knowledge of trade, languages and religious learning that put him in a useful position of being able see the big picture. Although born into Malay society, he was not a conventiona Malay, and remained a "global nomad, giving him an outsider's perspective. and looked for the moral aspect f what socio-economic system would be of benefit to the many. In his writings, sees the positives with the coming its rational and enlightened thinking might be able to rehabilitate what was then perceived to be a stagnant Malay society, though he wasn't blind to the foibles of the British either.

\section{LAW AND ORDER}

Much of Munshi Abdullah's writing focuses on good governance and the moral leadership of rulers. He believes that well-governed settlements, that look after their populations (or "stakeholders" will thrive with a reputation for just law and order, trade, financial reliability, probity, hospitalty and profit making. Asingaxample he ciles the Bitish in Farquhe, air Thoo specifally Colone right hand man, in the founding yeas of the Singapore colony.

"It was Mr Farquhar's nature to be patient and tolerant of other people's faults; and he treated both rich and poor alike, never looking on one person as more importan than another. If a man however poor and lowly came to him with a complaint he would attend to him quickly and listen carefully, giving advice and direction until the man's mind was set at rest, so that he returned home full of gratitude. Whenever he travelled about in his carriage or on horseback the rich and the poor, and the children too, saluted him and he at once geturned the complin to the "has ever

He compares this with the actions of British "paid off" for the lands where Singapore was founded. He and his Prime Minister were given a monthly allowance which led him to succumb to the pleasures of wealth and gluttony and grew indifferent to the financial and social welfare of his subjects. The Sultan degenerated into a morally-corrupt individual who would be considered today a violent sexual offender, and was so self-centred that he sold his descendant's legacy to the British. The British, he goes on later encouraged people to grow rice surrounding the new colony of Malacca which allowed many commo
people, with hard work, to become

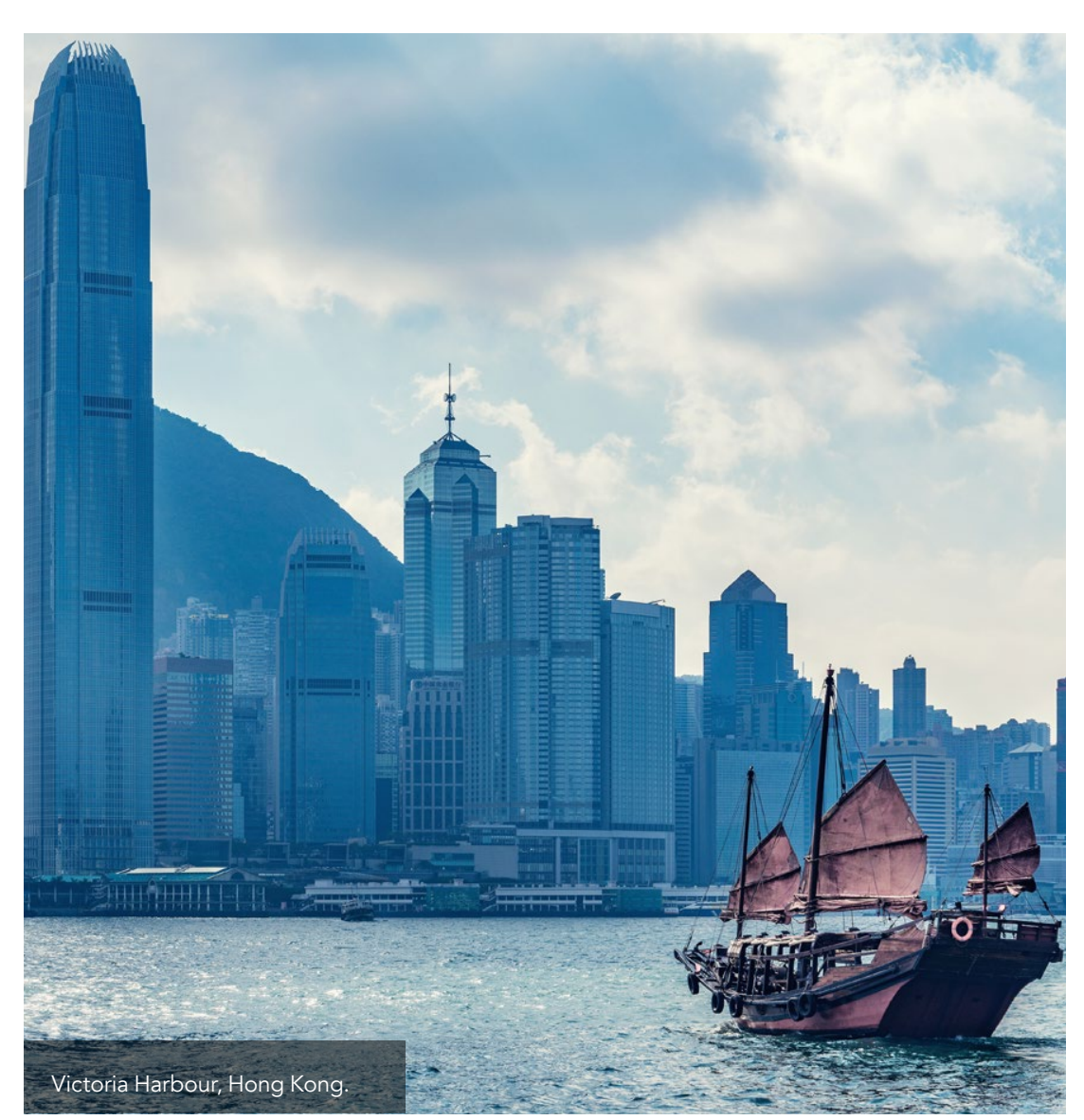

The Silk Road brought economic advantage... but also spread ideas and beliefs, and Hinduism, Buddhism, Christianity and Islam were all carried along with trade goods.

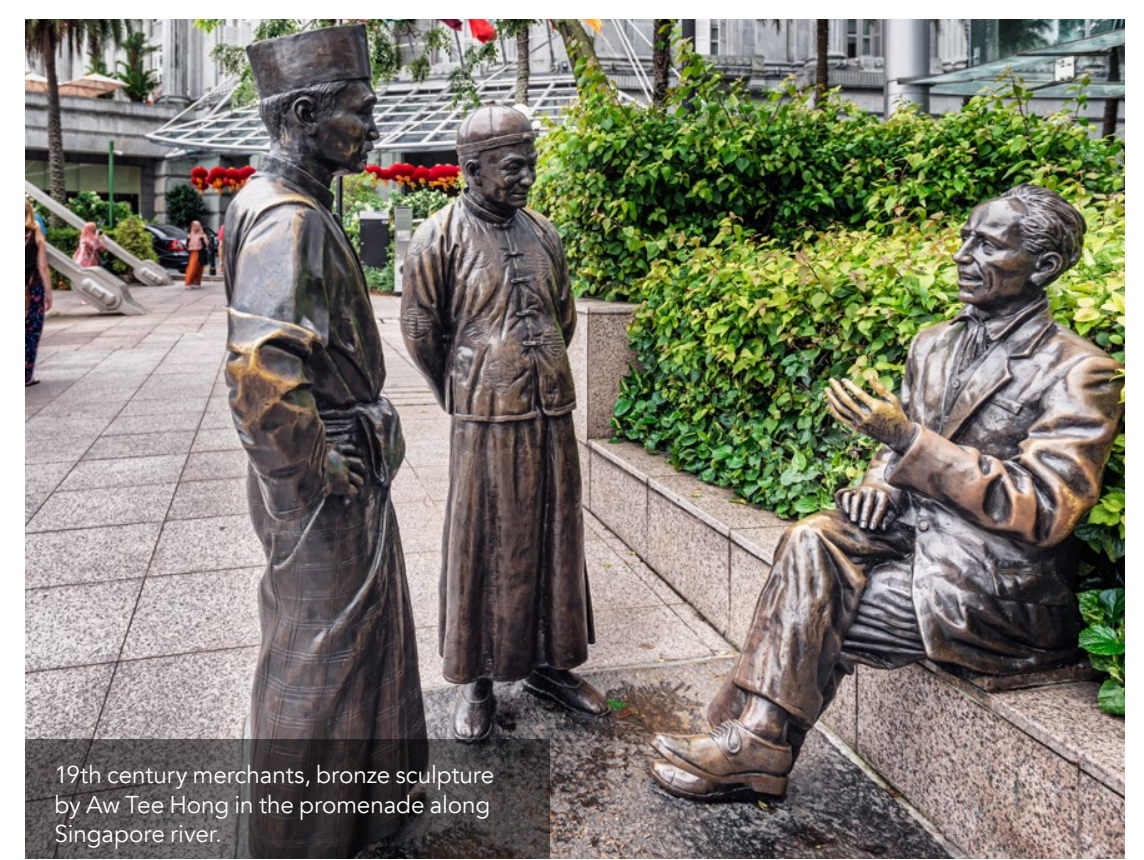


economically independent. This and developed the area.

\section{BENEFICENT AUTOCRACY}

The form of governance of the Sultan under the kerajaan feudal system is also
critiqued. He describes fights breaking out between the supporters of the Sultan and the "local" population of Singapore, who were a mixture of many different Asian peoples. He insinuates that the Malay raja had descended into mere gangsterism and it was only the actions of the British that protected the latter
against the former; "If they had not all against the former; "If they had not all been afraid of Colonel Farquhar they would have gone on killing each other every day without stopping."

The political system used by the British is also praised. The Malay kerajaan system focused all power in the hand ornate court, which meant that if a misgoverned, then the people would inevitably suffer. While being far from a modern democratic system, the British used the more pragmatic kapitan form of governance, perhaps borrowed from the Dutch in Malacca, which although autocratic in a neo-Platonic way, also granted certain autonomy to the Chinese Malay, Indian and Eurasian communities.

It used culturally-specific notions of shame to settle disputes amicably withou resort to abbitation through the rule of wirten law, and thre were several judicion The governorappointed kapitan community would themselves appoint village elders, so most day-to-day problems could be easily resolved between these two sides.

\section{WEALTH AND GOOD MANNERS} The last of the Hikayat Abdullah concern the proper relationship between material acquisition and good behaviour. One of the criticisms he has of the prosperity of Singapore is the way wealth has a negative impact, in that people's wor becomes connected more to their material possessions than their education "grmorals. Or as he more cryptically put it grasshoppers had become eagles, bed-

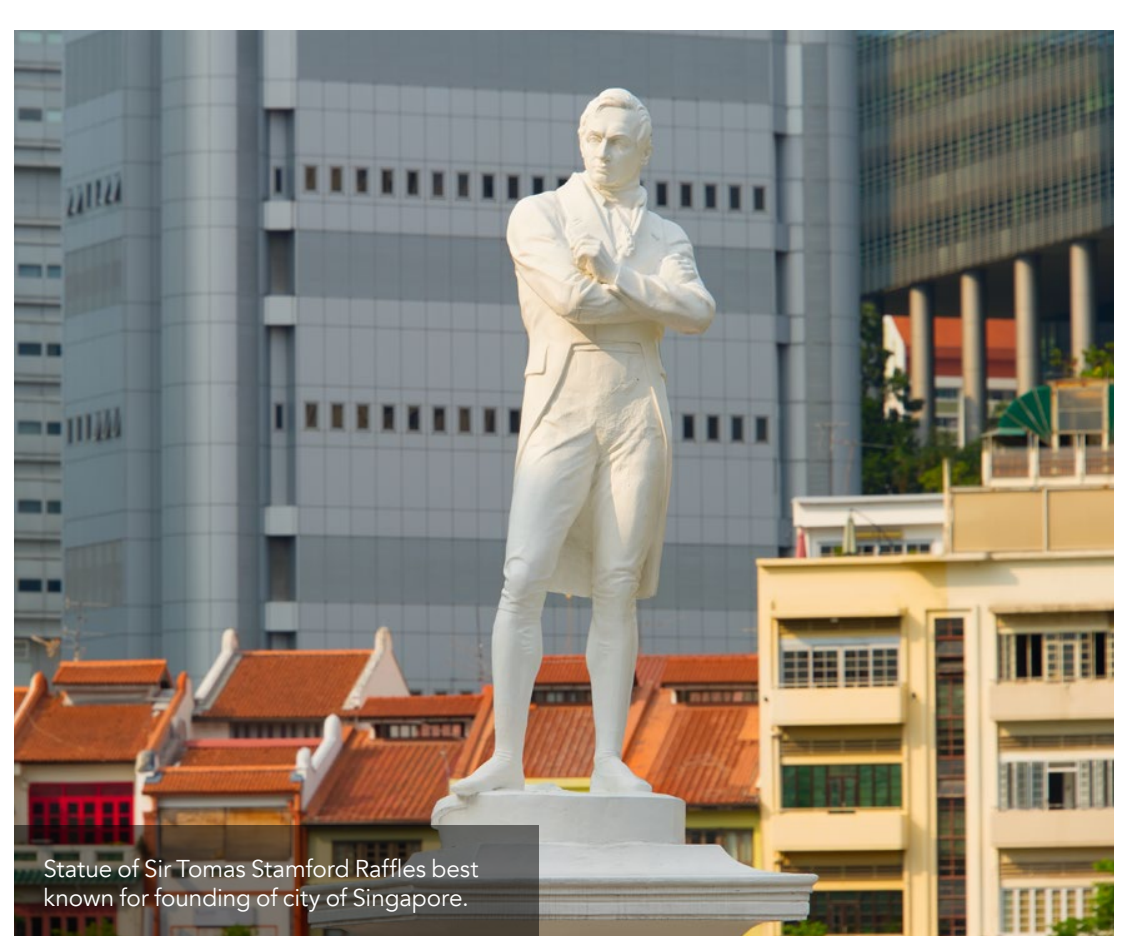

Hikayat Abdullah is used as snapshot of an Asian culture and economy that is experiencing change and that there are choices to be made by the leaders of these societies both financial and spiritual.

Again, Abdullah uses the British as an example of how the pursuit of enlightenment can be balanced amongs financial matters. He recounts how Sir Stamford Raffles, the British East India Company's preeminent representative, court's children be sent to India for a "British" education in order that they would become better rulers when they took over power, and encourage more of his Malay people to enter trade and be part of the new economy The Sultan however, refused citing various logistical and emotional obstacles. Abdullah seizes upon this as evidence of the reluctance of the indigenous cultures to adapt to the changing world around them and reform their societies in order not only to increase wealth but also to be morally better.

Some think that this shows an almost blind worship of the superiority of the British civilisation by Abdullah, but Chong asse it's more likely that he's propagating inevitably have to adapt to Western constitutional and scientific reforms, which of course turned out to be broadly true. He believed that the Malays, Chinese and Indians that he discoursed with would whe realse the prescience or his oullook when he asserted that the Europeans change was coming whether they prepared for it or not

CONCLUSION

In this paper, Hikayat Abdullah is utilised as snapshot of an Asian culture and. economy that is experiencing change and that there are choices to be made by the leaders of these societies both financial and spiritual. As Chong says, Abdullah examines the "modernisation of Asian societies confronted with 'progressive' civilisations improving their people's lives through technological and scientific revolutions. "While there are no clear cut answers given out by Abdullah, it can be argued that the societies the opportunity of mastering the coming of colonialism offers traditional

\section{Bal Behind the Research}

$\div$ Alan Chong

Aminision $\quad$ E: orchestraljoy@yahoo.com.sg T: $+65-94577620$

\section{Research Objectives}

Dr Alan Chong's research explores international relations Southeast Asia, and the foreign policy, political economy and political thought of Singapore.

\section{Detail}

DrAlan Chong

53 Meyer Road, \#06-05

Bio

Alan Chong is Associate Professor at the S. Rajaratnam

School of International Studies in Singapore. He specilises

in the study of Southeast Asian international relations and

advocates for non-western perspectives to the theorising

of the international and the global for nuance and richness.

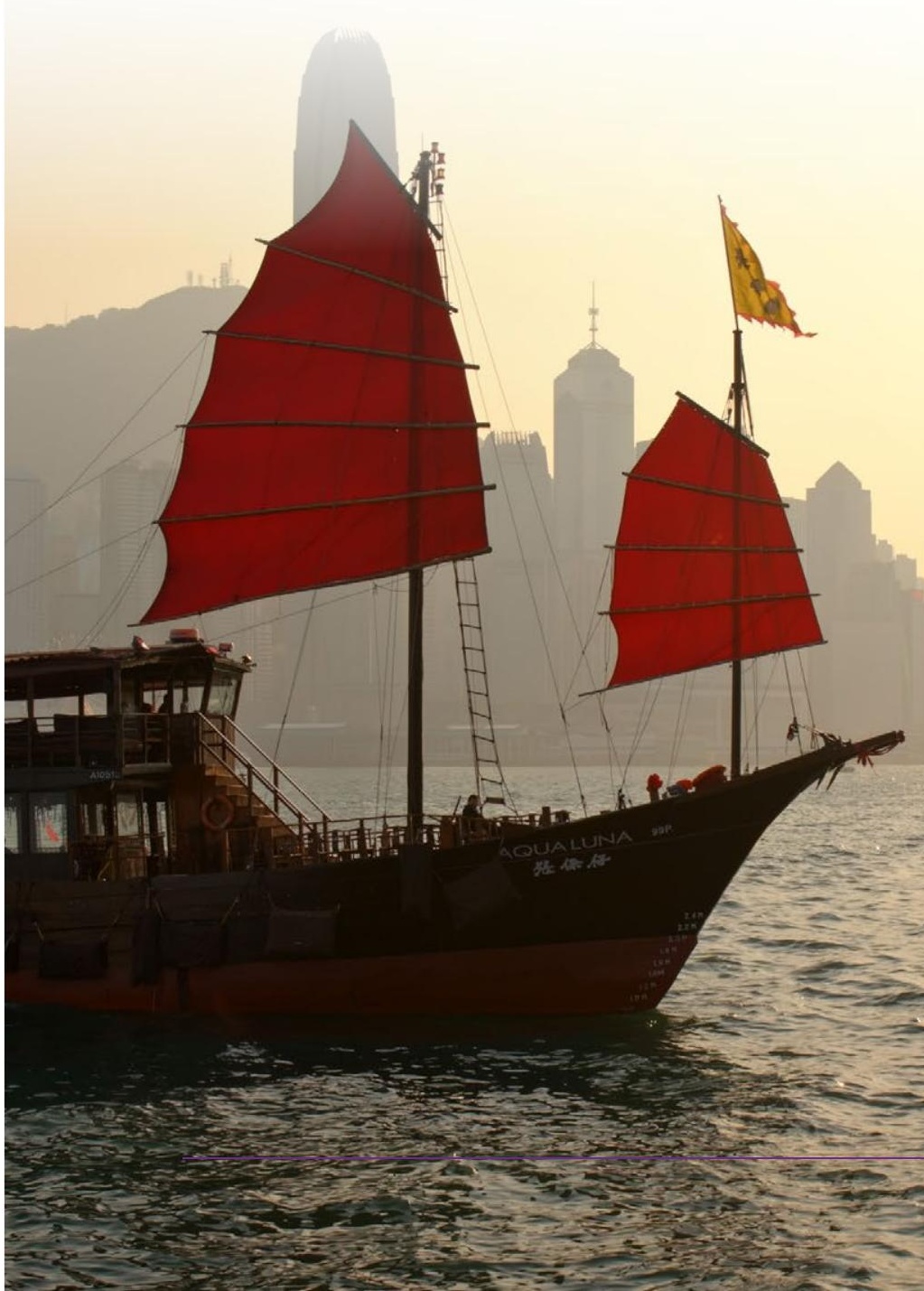

\section{References}

Chong A (2018) Ethical political economy: Lessons from 219-231https://doil of Comparative Politics 2018, Vol
org/10.1177/2057891117749948

Chong A (2017) Mercantile harmony: The ancient Silk Roads as intercultural meeting points amongst monks, pilgrims and merchants. Unpublished paper presented at the China's Belt and Road Initiative: Opportunities and Challenges conference organized by Vietnam National University and the Konrad
Adenauer Stiftung, Hanoi, Vietnam, 6 October 2017 .

Chong A (2012) Premodern Southeast Asia as a guide to international relations between peoples: Prowess and Alternatives: Global, Local, Political 37(2): 87-105. https://doi org/10.1177/0304375412444808

\section{Personal Response}

What criticisms of the British are made

II Although Abdullah comes across in first impressions as an unabashed Anglophile, close reading of the Hikay practised more patient empathy towards Malay culture. By gaining the latter's trust instead of simply imposing the frame of modernity as a transparent and legalistic order, British colonialism might have gained willing adherents modernity might have been less painful for the follow of kerajaan. Subsequent British Malayan colonial officials' biographies have attempted to downplay their colonial high-handedness. In this regard, the Hikayat Abdullah stands out as the more authentic voice treating the local
perspective on colonial modernisation. 